\title{
EFEKTIVITAS STATEGI PEMBELAJARAN "SEMANTIC MAPPING" DALAM MENINGKATKAN PENGUASAAN KOSAKATA BAHASA INGGRIS MAHASISWA
}

\author{
Fitri Senny Hapsari ${ }^{1}$, Natalia Tri Astuti ${ }^{2}$, Nurul Frijuniarsi ${ }^{3}$ \\ Program Studi Teknik Industri, Universitas Indraprasta PGRI Jakarta \\ Email: fitrisennyhapsari@gmail.com ${ }^{1}$
}

\begin{abstract}
Abstrak
Kosakata memainkan peran penting dalam mempelajari bahasa Inggris. Mahasiswa membutuhkan banyak kosakata untuk menyampaikan dan mengekspresikan ide mereka atau untuk memahami teks bacaan. Para siswa yang memiliki penguasaan kosakata yang rendah akan menemukan kesulitan untuk memahami bahasa Inggris baik lisan maupun tulisan. Teknik yang menarik dan yang dapat memotivasi diperlukan dalam mengajar kosa kata untuk merangsang mahasiswa agar menjadi lebih aktif. Semantic mapping adalah strategi pembelajaran visual untuk perluasan kosakata dan pengetahuan dengan menyajikan kategori kata-kata yang terkait satu sama lain. Stategi ini dapat membantu siswa menemukan hubungan antara kata-kata yang telah mereka ketahui, dan merekapun dapat belajar kata-kata baru juga. Penelitian ini bertujuan untuk mengetahui apakah strategi semantic mapping dapat membantu mahasiswa dalam meningkatkan penguasaan kosakata mereka. Penelitian ini menggunakan metode penelitian tindakan kelas, dilakukan dalam dua siklus yang mencakup tindakan prosedur penelitian seperti perencanaan, pelaksanaan, pengamatan, dan refleksi. Hasilnya secara eksplisit menunjukkan bahwa strategi semantic mapping mampu meningkatkan penguasaan kosakata mahasiswa karena hasilnya menunjukkan nilai rata-rata mahasiswa meningkat dari 60 menjadi 73 pada siklus pertama dan 78 pada siklus kedua.
\end{abstract}

Kata Kunci : Strategi Pembelajaran, Semantic Mapping, Penguasaan Kosakata Mahasiswa

\begin{abstract}
Vocabulary plays an important role in learning English. Students need a lot of vocabulary to convey and express their idea or to comprehend the reading text. The students who have little knowledge of vocabulary will find difficulties to understand both written and spoken language. An interesting and motivating technique is needed in teaching vocabulary to stimulate students become more active. Semantic mapping technique is a visual strategy for vocabulary expansion and extension of knowledge by displaying in categories words related to one another. It can help student discover the relationship between the words which they have known, and they can learn new words also by using this strategy. This research is aimed to find out whether semantic mapping strategy can help students to improve their vocabularyy mastery. This study used a classroom action research method, conducted in two cycles by following the procedure of action research, planning, implementing, observing, and reflecting. The result explicitly shows that semantic mapping strategy indeed improve students' vocabulary mastery because the results showed the average score increases from 60 to 73 in the first cycle and 78 in the second cycle.
\end{abstract}

Key Words : Learning Strategy, Semantic Mapping, Students'Vocabulary Mastery

\section{PENDAHULUAN}

Bahasa Inggris adalah bahasa global yang sangat berperan dalam interaksi dan komunikasi (lingua franca) global seiring dengan kemajuan dan persaingan globalisasi. Penguasaan bahasa Inggris sebagai bahasa yang resmi digunakan di lebih dari 60 negara di dunia sangat penting karena hampir semua sumber informasi global dalam berbagai aspek kehidupan menggunakan Bahasa Inggris.

Mengingat pentingnya peranan Bahasa Inggris pemerintah Indonesia telah menetapkan Bahasa Inggris sebagai bahasa asing yang wajib dipelajari di sekolah untuk tingkatan SMP dan SMA. Sementara di jenjang perguruan tinggi prodi bahasa Inggris sudah banyak berdiri mengingat 
banyaknya peserta didik yang berminat mengambil konsentrasi bahasa internasional ini. Lebih dari itu bahasa Inggris pun memiliki tempat dalam kurikulum operasional pendidikan untuk jurusan di luar bahasa Inggris sebagai mata kuliah umum yang mendukung kompetensi peserta didik.

Peserta didik yang belajar di program studi selain bahasa Inggris tentulah beranggapan bahwa mata kuliah bahasa Inggris merupakan bahasa asing yang sulit untuk dipelajari karena tidak sering digunakan dalam berkomunikasi pada konteks keseharian. Hal tersebut berdampak dalam kegiatan perkuliahan dan dilakukan antara dosen dan mahasiswa. Dengan kata lain, sangatlah tidak mudah dalam mempelajari bahasa asing bagi para pembelajar di Indonesia pada khususnya. Ada banyak hal yang harus disesuaikan ketika belajar bahasa inggris karena terdapat perbedaaan baik dalam kosakata ataupun struktur bahasa jika bandingkan dengan bahasa Indonesia yang merupakan bahasa utama mahasiswa (L1).

Kendala di atas tentunya menjadi perhatian bagi penyelenggara pendidikan di perguruan tinggi. Oleh karena itu di Prodi Teknik Industri Unindra bahasa inggris diberikan porsi yang cukup besar untuk mata kuliah bahasa Inggris. Mahasiswa mendapatkan mata kuliah bahasa Inggris dalam dua tingkatan yaitu "English for General " di semester pertama dan kemudian dilanjutkan pada semester dua dengan " English for Industrial Engineering" dengan masing-masing bobot 2 sks. Hal tersebut dimaksudkan agar mahasiswa dapat mempelajari bahasa inggris mulai dari tingkatan dasar (umum) hingga spesifik (khusus) sehingga dapat mendukung kompetensi mereka sebagai mahasiswa teknik industri.
Penguasaan bahasa Inggirs bukanlah sesuatu yang mudah untuk dipelajari sendiri oleh mahasiswa. Seperti bahasa Indonesia, bahasa Inggris memiliki empat keterampilan yang harus dikuasai. Harmer (2007) mendeskrisikan bahasa Inggris memiliki empat keterampilan dasar yang meliputi reading, listening, writing dan speaking. Empat keterampilan ini memang terpisah-pisah satu sama lain, namun memiliki keterkaitan, bahkan bisa digabungkan satu sama lain. Brown (2007) mengatakan bahwa a course that deal with reading skills, then, will also deal withrelated listening, speaking and writing. Sebelum mempelajari empat keterampilan ini, hal utama yang harus dimiliki siswa adalah perbendaharaan kosakatanya. McKeown (2002) argue that vocabulary knowledge is the heart of a language comprehension and use. atau kosakata adalah salah satu kunci dalam pemahaman. Penelitian ini akan fokus dalam pengajaran kosakata mengingat pengalama penulis sebagai dosen di prodi teknik industri mengalami kesulitan dalam proses mengajar dikarenakan penguasaan kosakata bahasa Inggris mahasiswa yang masih lemah. Hal tersebut dapat dimengerti mengingat latar belakang mahasiswa yang jarang menggunakan bahasa Inggris dalam konteks keseharian serta minat mahasiswa yang tidak terlalu besar dalam pembelajaran bahasa asing. Selain itu strategi atau cara pengajaran kosakata yang kurang interaktif dapat menjadi salah satu faktor yang membuat rendahnya motivasi mahasiwa dalam mengembangkan perbendaharaan kosakata bahasa Inggris mahasiwa, seperti juga yang dipaparkan oleh Huyen (2003) the factors are: first, they consider the teacher's explanation for meaning or definition, pronunciation, 
spelling, and grammatical functions as boring thing.

Sebagai pengajar tentulah dituntut memiliki keterampilan dan kreatiftas dalam menyampaikan materi pembelajaran kepada mahasiswa. Penggunaan metode yang tepat dalam pengajaran kosakata kepada mahasiswa akan berdampak terhadap perkembangan jumlah perbendaharaan kata bahasa Inggris yang mereka kuasai sehingga dapat merangsang mahasiwa menggunakan kosakata mereka dalam keterampilan mendengar, berbicara, menulis maupun membaca.

Semantic mapping merupakan salah satu strategi pembelajaran yang dapat digunakan dengan untuk mengembangkan penguasaan kosakata. Huynh (2002) menyatakan bahwa semantic mapping terdiri dari kategori yang sangat luas dari organisator grafik dan dapat digunakan dalam berbagai macam bidang pembahasan untuk membantu siswa memahami hubungan dan membangun konsep tentang topik yang luas.

Dari penjelasan beberapa ahli di ataskan bahwa strategi pembelajaran semantic mapping merupakan suatu pembelajaran yang memiliki visualisasi berbentuk diagram, grafik yang menjabarkan suatu kata yang disebut subject (ide pokok) melalui penulisan beberapa sub-sub ide yang mendeskripsikan subjek tersebut. Sub-sub ide ini dapat berbentuk kata atau frasa yang tentunya saling berhubungan dengan subjek. Bentuk dari refresentas subjek dan sub-sub ide nya dapat dapat diletakkan di dalam suatu bentuk seperti segitiga, lingkaran atau kotak. Atau dengan visual yang ebih menarik Semantic mapping ini dapat juga disajikan dalam bentuk pohon yang subjeknya sebagai batang sedangkan sub-sub ide berada pada cabang. Elaborasi dari subsub ide berada pada ranting-rantingnya.

Berikut adalah contoh dari representasi penerapan semantic mapping untuk salah satu kata bahasa Inggris yang dipelajari mahasiswa teknik Industri.

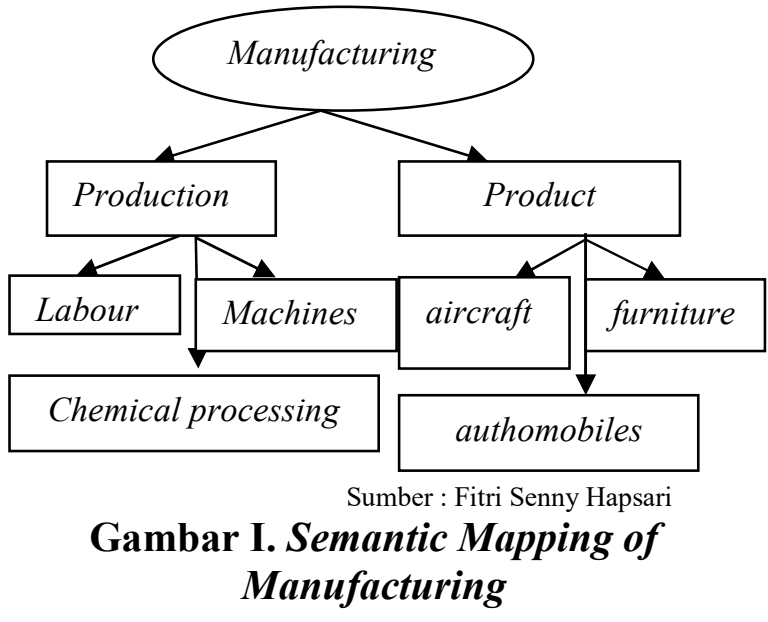

Berdasarkan pada tinjauan latar belakang yang telah dipaparkan di atas, penulis menerapkan strategi pembelajaran semantic mapping dalam upaya meningkatkan penguasaan kosakata bahasa Inggris Mahasiswa di Prodi Teknik Industri Universitas Indraprasta PGRI.

\section{METODE}

Classroom action research atau penelitian tindakan kelas (PTK) merupakan metode yang digunakan dalam melaksanakan penelitian ini. Penelitian dilaksanakn dalam bentu memberi tindakan dalam rangka memperbaiki kegiatan maupun hasil pembelajaran yang dilakukan di kelas, hal serupa pun mengacu pada pendapat dari I.G.A.K Wardani, Kuswaya Wihardit; Noehi Nasution (2006) yang memaparkan definisi penelitian tindakan kelas sebagai berikut: "penelitian tindakan kelas adalah penelitian yang dilakukan oleh guru didalam kelasnya sendiri melalui refleksi diri, dengan tujuan untuk memperbaiki kinerjanya sebagai guru, sehingga hasil belajar siswa menjadi meningkat." Menurut Suhardjono (2011) 
Penelitian ini adalah tindakan yang nyata yang diyakini lebih baik dari yang biasa dilakukan untuk memperbaiki dan atau meningkatkan mutu pembelajaran di kelas.

Subjek yang diteliti pada penelitian ini adalah mahasiswa teknik industri kelas R.2A Universitas Indraprasta PGRI semester dua tahun akademik 2018-2019 yang berjumlah 33 mahasiswa. Disisi lain objek penelitian ini adalah penerapan strategi pembelajaran semantic maping untuk meningkatkan penguasaan kosakata bahasa Inggris mahasiswa.

Penelitian tindakan kelas yang dilakukan peneliti melewati 2 siklus yang yang setiap siklusnya terangkai dari 4 tahap yaitu perencanaan (planning), kemudian ditindaklanjuti dengan tindakan (acting), kegiatan tindakan yang diberikan kemudian diamati secara sistematis dalam tahap pengamatan (observating), dan direfleksikan berdasarkan hasil pengamatan (reflecting). Hasil refleksi ditiap siklusnya akan digunakan untuk merencanakan dan mengimpleentasikan tindakan siklus kedua, dan siklus-siklus berikutnya, sebagai bentuk rencanapada tahap selanjutnya (replanning). Setiap siklus dilakukan untuk dua kali pertemuan tatap muka di kelas. Berdasarkan pelaksanaan PTK ini, penulis sudah memperoleh peningkatan terkait tujuan pelaksaan penelitian hanya dalam 2 siklus.

Waktu pelakaksanaan penelitian ini adalah dilaksanakan pada semester genap tahun akademik 2018-2019 tepatnya selama bulan Maret - April 2019. Siklus satu dilakukan di minggu ketiga dan keempat pada bulan April, sedang kan siklus dua adalah pada minggu ke pertama dan ke dua pada bulan April. Instrumen yang digunakan guna menghimpun data terdiri dari : (1) Pedoman Observasi digunakan untuk mengamati aktivitas mahasiwa selama proses pembelajaran yang dilakukan disetiap siklus. (2) Penerapan dan pemberian tugas menggunakan strategi pembelajaran semantic mapping dan tes menulis menggunakan kosakata bahasa Inggris Bahasa Inggris dengan istilahistilah teknik industri sesuai dengan rencana pembelajaran semester (RPS) mata kuliah Bahasa Inggris Teknik (English for Industrial Engineering Student)

Catatan lapangan yang digunakan untuk mencatat semua peristiwa penting yang terjadi saat penelitian dilaksanakan pada tahap awal hingga akhir.

Setelah mengumpulkan data yang didapat selama penelitian, selanjutnya penulis melakukan analisis dengan teknik deskriptif kuantitatif. selanjutnya penulis akan mendeskripsikan apakah data yang telah terkumpul dapat menjawab dan memberikan bukti pembenaran atau ketidakbenaran dari pertanyaan penelitian.

Teknik analisis data yang dilakukan melawati beberapa tahap yaitu : (1) pengecekan data; dalam hal ini data yang terkumpul dikoreksi kembali mengecek kebenaran yang sesuai dengan kebutuhan. (2) seleksi data; data yang telah didapatkan kemudian dipilih, dengan tujuan memperoleh data yang sesuai dengan tujuan penelitian, menglasifikasikan data, yaitu dengan cara mengelompokan data untuk mempermudah proses penyimpulan, (4) Tabulasi data;setelah data diklasifikasi, kemudian ditabulasi untuk mendapatkan data yang empiris.

\section{HASIL DAN PEMBAHASAN}

Penelitian ini melewati dua siklus. Siklus I dan II dilakukan melalui 4 tahap. setiap siklus memerlukan dua kali pertemuan tatap muka di kelas dengan bobot 2 sks setiap minggunya ( 2 x 50 menit). 


\section{Siklus I}

a. Perencanaan

Pada siklus I, peneliti memulai kegiatan dengan menyiapkan perangkat ajar seperti daftar hadir dan daftar penilaian mahasiswa, serta RPS untuk mata kuliah Bahasa Inggris Teknik . Sebagai upaya memaksimalisaikan proses perencanaan, peneliti melakukan observasi terkait nilai mata kuliah bahasa Inggris dengan menghimbun nilai mahasiwa pada pertemuanpertemuan sebelum dilakukannya penelitian. Peneliti pun mempersiapkan materi dan bahan ajar yang didesign dengan penerapan strategi pembelajaran semantic mapping.

b. Pelaksanaan

Pertemuan 1

Pada pertemuan pertama dosen memaparkan materi sesuai dengan RPS, yaitu materi pada teks "Production Control". Selanjutnya dosen meminta mahasiswa untuk bersama-sama menterjemahkan teks tersebut menggunakan alat bantu kamus, setelah mendiskusikannya bersama-sama, dosen menuliskan satu kata dalam sebuah lingkaran di papan tulis dan membuat mapping untuk sub-sub ide berupa kata atau frasa yang berhubungan dengan kata utama (seperti pada gambar 1 di atas). Kemudian dosenpun meminta mahasiwa untuk memilih satu kata dala teks yang telah dibahas untuk dibuat pokok utama dalam bentuk semantic mapping. Untuk tinak lanjut dari penerapaan strategi tersebut, dosenpun memberikan pekerjaan rumah dengan membuat semanticmapping pada dua kata pokok utama.

Pertemuan II

Awal pertemuan II, diawali dengan memeriksa tugas mahasiwa dan meminta beberapa mahasiwa membuat mapping untuk ide pokok pada tugas mahasiwa yang lain. Selanjutnya dosen pun memberikan tes dengan meminta mahasiwa mengisi kata yang tepat untuk kalimat yang tidak utuh (jumbled sentence question)

c. Refleksi

Hasil dari pengamatan pada pertemuan 1 dan 2, penulis merefleksikan setiap temuan sebagai bahan evaluasi untuk kembali melakukan penelitian. Pada pertemuan pertama, sebagian mahasiwa tidak membawa kamus bahasa Inggris sehingga mereka kesulitan untuk membuat semantic mapping pada ide pokok yang diberikan.lebih dari itu terlihat beberapa mahasiwa masih kebingungan dengan konsep yang diajarkan dosen mereka cenderung bingung untuk menemukan perluasan makna kata yang dicari. Sedangkan untuk tes kosakata berupa jumbled sentence question yang diperolah mahasiswa pada pertemuan kedua ratarata 73. Dengan nilai terendah 50 dan nilai tertinggi 76. Angka-angka tersebut belum memenuhi indikator kesuksesan yang peneliti tetapkan yaitu dengan 75 untuk nilai rata-rata, maka penelitian dilanjutkan dengan siklus II.

\section{Siklus II}

a. Perencanaan

Berdasarkan hasil tes dan refleksi pada siklus I, peneliti membuat aturan tegas bahwa setiap mahasiwa harus membawa kamus bahasa Inggris dan kembali meberikan contoh serta arapan terkait pembentuan semantic mapping pada suatu kata ide pokok.

\section{b. Pelaksanaan}

Pertemuan 1

Pada pertemuan pertama siklus II dosen meberikan teks bacaan dengan judul"Management Contol System". Selanjutnya dosen kembali memberikan 
contoh kata yang sudah diberikan pada dua pertemuan selanjutnya, sehingga sebagian mahasiwa merasa mampu untuk membuat mapping karena mereka pernah mempelajari kata tersebut. Mahasiwa pun semakin percaya diri untuk membuat mapping pada kata-kata yang dijadikan ide pokok lainnya. Penelitipun memberikan arahan bahwa dalam pembelajaran bahasa Inggris mahasiwa diwajibkan membawa kamus masing-masing sehingga dalam proses pengerjaan mapping mahasiwa dapat lebih fokus mencari kata-kata terkait lainnya. Dosenpun memberikan tugas membuat 5 semantic mapping dari kosakata yang terdapat dari teks yang mereka pelajari.

\section{Pertemuan II}

Pada pertemuan kedua dosen memberikan kesempatan kepada mahasiwa untuk menuliskan hasil semantic mapping di papan tulis. Dosen meminta mahasiwa yang memaparkan mapping untuk melakukan komunikasi aktif dengan mahasiwa lainnya untuk mengisi sub-sub ide pada kata pokok tersebut. Setelah diskusi dosen memberikan tes yang menguji penguasaan kosakata mahasiwa yaitu meminta mahasiwa menyusun semantic mapping pada beberapa kata yang berkaitan dengan tema " Production and Management Control System" dan mengisi jumbled sentence question dengan tema yang sama pada bagian tes menyusun semanic mapping.

\section{c. Pengamatan}

Pada tahap pengamatan di siklus ke II peneliti merasakan antusia dan semangat yang meningkat pada pertemuan pertama, karen pada tahap tersebut mahasiwa telah cukup familiar dengan ide pokok yang dipelajari. Pada pertemuan kedua seluruh mahasiwa sudah membawa kamus bahasa Inggis sehingga mereka dapat lebih fokus mencari sub-sub ide yang relevan tanpa terganggu mahasiswa lain yang meminjam kamus seerti pada kejiaan di siklus pertama. Lebih lanjut setelah sering menyusun semantic mapping pada suatu ide pokok, perbendaharaan kata mahasiswapun meningkat yang ditandai dengan pengerjaan yang lebih cepat dan tepat saat menyusun mapping untu pokok kata yang diberikan.

d. Refleksi

Hasil dari siklus II menunjukkan bahwa mahasiswa memperoleh kemajuan yang lebih baik dari pada pada siklus I. Semua mahasiswa mampu menyusun semantic mapping tekait ide pokok yang diulas. Hal terbut member dampat terhadap meningkatnya hasil tes berkaitan dengan penguasaan kosakata bahasa Inggris mahasiwa dengan rata-rata nilai 78. Dengan nilai terendah 60 dan nilai tertinggi 85 . Oleh karena itu tindak lanjut (siklus) berikutnya tidak diperlukan karena indikator penelitian sudah tercapai.

Penerapan strategi pembelajaran semantic mapping sebagai upaya peningkatan penguasaan kosakata mahasiswa, berdampak positif dan efektif berdasarkan hasil tes yang dilakukan sebelum tindakan hingga siklus terakhir. Di bawah ini merupakan table nilai tes penguasaan kosakata mahasiswa.

Tabel 1.1 Nilai Tes Mahasiswa

\begin{tabular}{cccc}
\hline Nilai & $\begin{array}{c}\text { Sebelum } \\
\text { PTK }\end{array}$ & $\begin{array}{c}\text { Siklus } \\
\text { I }\end{array}$ & $\begin{array}{c}\text { Siklus } \\
\text { II }\end{array}$ \\
\hline Terendah & 40 & 50 & 60 \\
Tertinggi & 70 & 79 & 85 \\
Rata-rata & 60 & 73 & 78 \\
\hline
\end{tabular}

Setelah mendapakan nilai yang meningkat dari tahap sebelum pelaksanaan hingga setelah melewati 2 siklus penelitian, 
strategi pembelajaran semantic mapping merupakan cara yang efektif untuk diterapkan dalam mengembangkan dan meningkatkan pengasaan kosakata bahasa Inggris mahasiswa. Hal ini sejalan dengan penelitian terdahulu yang dilakukan oleh Musfina Rahma, Muhammad Sukirlan, Sudirman (2015), di mana hasil penelitian menunjukkan bahwa semantic mapping memberikan dampak yang signifikan terhadap pengingkatan penguasaan kosakata bahasa Inggris siswa.

Melalui penerapaan strategi pembelajaran semantic mapping sangat cocok untuk mengembangkan kreatifitas peserta didik untuk mengolah informasi yang sebelumnya dimiliki dengan cara menambahkan pengetahuan baru melalui tahap mapping melalui pencarian kata-kata baru yang berkaitan dengan ide pokok nya (subjek).

\section{SIMPULAN}

Berdasarkan hasil penelitan, dapat disimpulkan bahwa penerapaan strategi pembelajaran semantic mapping efektif memberikan dampak yang baik terhadap peningkatan kosakata bahasa Inggris mahasiwa teknik industri. Penerapaan strategi semantic mapping menstimulus mahasiwa untuk kreatif mengaikan suatu ide pokok yang diperluas kedalam sub-sub ide melalui pencarian kosakata yang secara aktif mereka susun secara relevan dan sistematis. Hal ini berdampak terhadap bertambahnya perbendaharaan kata mahasiwa ketika mempelajari suatu kata, sehingga secara otomatis dalam satu bahasan mahasiwa memperoleh lebih dari satu kata atau frasa yang baru. Untuk itu penulis menyarankan kepada guru ataupun dosen untuk mengoptimalkan pengajaran kosakata bahasa Inggris melalui penerapan strategi pembelajaran semantic mapping karena akan lebih menstimulus keaktifan mahasiwa dalam mengolah kata-kata baru menjadi lebih bermakna dan bertambah secara kuantitinya.

\section{DAFTAR PUSTAKA}

[1] Harmer, Jeremy. The Practice of English Language Teaching. Essex, England: Pearson Education Limited, 2007.

[2] Brown, H.D. Teaching by Principles: An Interactive Approach to Language Pedagogy (3 rd edn.). New York: Longman, 2007.

[3] McKEOWN, M. G., L. Bringing words to life: Robust vocabulary instruction. New York, New York: Guilford, 2002.

[4] Huyen. Learning Vocabulary through Games: The Effectiveness of Learning Vocabulary through Games. Asian EFL Journal. Retrieved 22nd October, 2008 from http:/www.asian-efl-journal.com, 2003.

[5] Huynf, Uyen, Linda Lizaragga dan Brenda Wilkerson. How do Semantic Maps Build Vocabulary. December ,2002.

[6] I.G.A.K Wardani, Kuswaya Wihardit; Noehi Nasution, Penelitian Tindakan Kelas, (Jakarta Universitas Terbuka, 2006), hal.1.4

[7] Suhardjono, Supardi. Strategi Menyusun Penelitian Tindakan Kelas. Yogyakarta : Adhi, 2011.

[8] Musfina Rahma, Muhammad Sukirlan, and Sudirman Sudirman. "Teaching Vocabulary through Semantic Mapping Technique at The Second Year of Smp". U-JET Unila joural of english teaching, vol 4, no. 9, pp, 2015. 